\title{
Temporal variability in the abundance of ammonia- oxidizing bacteria vs. archaea in sandy sediments of the Douro River estuary, Portugal
}

\author{
Catarina M. Magalhães ${ }^{1, *}$, Ana Machado ${ }^{2}$, Adriano A. Bordalo ${ }^{1,2}$ \\ ${ }^{1}$ Centre of Marine and Environmental Research, Rua dos Bragas No. 289, 4050-123 Porto, Portugal \\ ${ }^{2}$ Laboratory of Hydrobiology, Institute of Biomedical Sciences, University of Porto, Largo Prof. Abel Salazar No. 2, \\ 4099-003 Porto, Portugal
}

\begin{abstract}
We studied the relative abundance of betaproteobacterial ammonia-oxidizing bacteria (Betaproteobacteria AOB) vs. ammonia-oxidizing archaea (AOA) in the intertidal sediments of the Douro estuary by quantifying Betaproteobacteria AOB and AOA amoA genes over 12 mo. We also evaluated the diversity of AOA in the sandy intertidal sediments of the estuary. Real-time PCR analysis showed that the abundance of Betaproteobacteria AOB amoA genes ranged from $0.8 \times 10^{6}$ to $7.5 \times$ $10^{6}$ copies $\mathrm{cm}^{-3}$ of sediment, corresponding to 0.8 to $8.4 \%$ of the total bacterial $16 \mathrm{~S}$ rRNA gene copies, while that of AOA amoA genes ranged from $0.9 \times 10^{5}$ to $8.6 \times 10^{5}$ gene copies $\mathrm{cm}^{-3}$ of sediment, corresponding to 0.8 to $25.9 \%$ of the total archaeal copies. Results revealed that bacteria dominated the ammonia-oxidizing community almost over the entire survey period, with Betaproteobacteria AOB:AOA ratios ranging from 1 to 39. Nitrification activity estimations based on the numerical abundance of Betaproteobacteria AOB and AOA amoA, and comparison with measured nitrification rates indicated that Betaproteobacteria AOB were the major contributors to the nitrification process. Phylogenetic analysis of AOA revealed that archaeal amoA sequences retrieved from Douro estuarine sediments were closely related to sequences previously found in the water column, in soils and sediments.
\end{abstract}

KEY WORDS: Bacteria $\cdot$ Archaea $\cdot$ Ammonia-oxidation $\cdot$ Nitrification $\cdot$ Sandy sediments

\section{INTRODUCTION}

Nitrification - the microbial oxidation of ammonia to nitrite and nitrate-occurs in a wide variety of environments and plays a central role in the global nitrogen cycle. Until recently, chemolithoautrophic ammonia-oxidizing bacteria of the classes Betaproteobacteria and Gammaproteobacteria were considered to be the only groups of microorganisms that are able to obtain energy via conversion of $\mathrm{NH}_{4}{ }^{+}$to $\mathrm{NO}_{2}^{-}$. However, the recent cultivation of an ammonia-oxidizing crenarchaeote (Könneke et al. 2005) has expanded our knowledge of the microbial communities involved in ammonia-oxidation, and thus in the global nitrogen cycle. This study was followed by other pioneering investigations that indicated the widespread distribu- tion of ammonia-oxidizing archaea (AOA) in the ocean water column and in sediments (Francis et al. 2005), in estuarine sediments (Beman \& Francis 2006, Dang et al. 2008), in natural and managed soils (Leininger et al. 2006) and in wastewater treatment plant bioreactors (Park et al. 2006). Presently, studies focusing on the quantification of the abundance of bacterial vs. archaeal amoA genes, and on their relative contributions to nitrification (Hallam et al. 2006a, Leininger et al. 2006, Wuchter et al. 2006, Caffrey et al. 2007, Mosier \& Francis 2008, Nicol et al. 2008, Santoro et al. 2008) are also emerging. Almost all quantitative studies indicate that amoA genes of AOA are more abundant than those of ammonia-oxidizing bacteria (Betaproteobacteria AOB) (Hallam et al. 2006a, Leininger et al. 2006, Wuchter et al. 2006, Agogué et al. 2008, Nicol 
et al. 2008), except for a few studies that found numerical dominance of Betaproteobacteria AOB in different coastal and estuarine sediment sites (Caffrey et al. 2007, Mosier \& Francis 2008, Santoro et al. 2008). Salinity, oxygen, sulphide, temperature and $\mathrm{pH}$ have been previously identified as important variables controlling the relative abundances of Betaproteobacteria $\mathrm{AOB}$ and AOA in estuarine and coastal sediments (Caffrey et al. 2007, Mosier \& Francis 2008, Nicol et al. 2008, Santoro et al. 2008). However, the environmental variables that drive the variability in Betaproteobacteria $\mathrm{AOB}$ and $\mathrm{AOA}$ over seasonal time scales are still poorly understood. In the present study, we estimated both Betaproteobacteria AOB and AOA amoA gene abundances over a 12 mo period in sandy intertidal sediments of the Douro River estuary, as well as important environmental variables and nitrification rates. Relationships between the abundances of these 2 groups of ammonia-oxidizers and nitrification rates were established to provide insights on their relative contributions to nitrification.

\section{MATERIALS AND METHODS}

Site description and sample collection. The study was conducted in an intertidal sandy flat, which is the dominant intertidal environment within the lower Douro River estuary (Vieira \& Bordalo 2000). These sediments are mainly composed of highly permeable coarse sand and gravel $(>0.5 \mathrm{~mm})$, with high positive redox potential values being measured within the $0.5 \mathrm{~cm}$ depth $(\mathrm{Eh}=144.9 \pm 20.1 \mathrm{mV})$. Although no data on oxygen levels in the layers beneath the surface are available, the sediment was colored slightly green on top, yellow from below the surface to approximately $6-8 \mathrm{~cm}$ depth and occasionally gray below $6 \mathrm{~cm}$, indicating that the sediments were oxygenated. These sediments were also characterized by a high mean chl a content and low values of total organic matter (see Table 2). This site has been physically, chemically and biologically characterized in previous studies (e.g. Mucha et al. 2003, Magalhães et al. 2005a,b). Monthly surveys were conducted between February 2002 and January 2003, during which 2 cores ( $3 \mathrm{~cm}$ diameter and $8 \mathrm{~cm}$ long) were collected at a single location. Cores were homogenized, stored in sterile plastic bags and transported to the laboratory in the dark in refrigerated ice chests. Subsamples of the homogenized sediment were immediately processed for the analysis of total organic matter, chl a content and nitrification rates, and further subsamples were frozen and stored at $-70^{\circ} \mathrm{C}$ until DNA extraction. Nitrification rates were measured in triplicate aerobic slurries by using the difluoromethane (DFM) inhibition technique (Miller et al. 1998), using subsamples of homogenized sediment retrieved from the same location. Nitrification rates were calculated by the difference between $\mathrm{NH}_{4}{ }^{+}$accumulation in treatments with and without DFM (Magalhães et al. 2005a).

Total cell counts. For total counts of microbial cells, $1 \mathrm{~g}$ of homogenized sediment sample was added to a mixture of $2.5 \mathrm{ml}$ saline solution $\left(0.2 \mu \mathrm{m}\right.$-filtered, $9 \mathrm{~g} \mathrm{l}^{-1}$ $\mathrm{NaCl})$ and $200 \mu \mathrm{l}$ Tween 80 (0.2 $\mu \mathrm{m}$-filtered, $12.5 \%$ $\mathrm{v} / \mathrm{v})$, and fixed with $1 \mathrm{ml}$ of formaldehyde $(0.2 \mu \mathrm{m}$ filtered, $4 \% \mathrm{v} / \mathrm{v})$. The slurries were stirred at $150 \mathrm{rpm}$ for $15 \mathrm{~min}$, and sonicated for 20 to $30 \mathrm{~s}$ at low intensity ( 0.5 cycle, $20 \%$ amplitude). Subsamples of the slurries were then stained with DAPI and incubated in the dark for 12 min (Porter \& Feig 1980). Samples were filtered onto black Nucleopore polycarbonate filters (Whatman, $0.2 \mu \mathrm{m}$ pore size, $25 \mathrm{~mm}$ diameter) under gentle vacuum and washed with autoclaved $0.2 \mu \mathrm{m}$-filtered distilled water. Membranes were set up on glass slides and cells counted at $1875 \times$ on an epifluorescence microscope (Laphot, Nikon).

Quantitative real-time PCR and cloning. Total community DNA was extracted from $1 \mathrm{~g}$ wet wt of sediment using an ultra powersoil DNA isolation kit (MoBio Laboratories). Reproducibility of the amount of DNA extracted was tested in triplicate sandy sediment samples $(\mathrm{CV}=14 \%)$. The efficiency of DNA extraction from sandy sediment samples was tested according to Okano et al. (2004) by adding a known number of Silicibacter pomeroyi cells to the sediment. The number of $S$. pomeroyi cells in liquid medium was determined with an epifluorescence microscope after DAPI staining, and nosZ gene copy numbers were calculated considering that $S$. pomeroyi has 1 nos $Z$ copy cell ${ }^{-1}$ (Moran et al. 2004). A total of $4.0 \times 10^{6} S$. pomeroyi cells were added to $1 \mathrm{~cm}^{3}$ of sandy sediment and DNA was extracted in triplicate as described above. The calculated nos $Z$ copy numbers, based on DAPI counts, were on average $8.0 \times 10^{6} \pm 3.2 \times 10^{5}$ cells $\mathrm{cm}^{-3}$ of sediment. The difference in nos $Z$ copy numbers between samples with and without target DNA addition as measured by real-time PCR was $2.2 \times 10^{6} \pm 3.0 \times 10^{5}$ cells $\mathrm{cm}^{-3}$ of sediment. Therefore, the extraction efficiency of the powersoil DNA isolation kit was $27.5 \pm 2.2 \%$, which is in agreement with DNA recovery efficiencies calculated in other studies (Mumy \& Findlay 2004, Okano et al. 2004). Quantitative PCR was conducted in a real-time PCR system (MiniOpticon CFB-3120, BioRad) to determine bacterial and archaeal 16S rRNA and amoA gene copy numbers using previously described primer sets (Table 1). PCR reactions were run in duplicate with $4 \mathrm{ng}$ of template DNA in $25 \mu \mathrm{l}$ reaction volume containing: $12.5 \mu \mathrm{l}$ of SYBR green supermix (BioRad), $2 \mu$ l of each primer $(10 \mu \mathrm{M}), 1$ to 
Table 1. Oligonucleotide probes used in this study

\begin{tabular}{|llll|}
\hline Target group & Primers & Sequence $\left(5^{\prime}-3^{\prime}\right)$ & Source \\
\hline Bacteria & $341 \mathrm{~F}$ & CCT ACG GGA GGC AGC AG & Muyzer et al. (1993) \\
& $534 \mathrm{R}$ & ATT ACC GCG GCT GCT GG & Suzuki et al. (2000) \\
Archaea & ARCH1-1369F & CGG TGA ATA CGT CCC TGC & Rotthauwe et al. (1997) \\
& PROK1541R & AAG GAG GTG ATC CRG CCG CA & Okano et al. (2004) \\
Betaproteobacteria & amoA-1F & GGG GTT TCT ACT GGT GGT & Francis et al. (2005) \\
AOB amoA & amoA-2R' & CCT CKG SAA AGC CTT CTT C & \\
Archaea amoA & Arch-amoAF & STA ATG GTC TGG CTT AGA CG & \\
& Arch- amoAR & GCG GCC ATC CAT CTG TAT GT & \\
\end{tabular}

$3 \mu \mathrm{l}$ of template and 5.5 to $7.5 \mu \mathrm{l}$ of nuclease-free water (Promega). All reactions were performed in white $0.2 \mathrm{ml}$ strips with ultraclear optical flat caps (BioRad). For all primer sets, the thermal cycle was programmed to $5 \mathrm{~min}$ of precycling at $94^{\circ} \mathrm{C}, 8$ cycles of $94^{\circ} \mathrm{C}$ denaturation for $30 \mathrm{~s}, 65^{\circ} \mathrm{C}$ annealing for $30 \mathrm{~s}$, and $72^{\circ} \mathrm{C}$ extension for $30 \mathrm{~s}$ followed by 27 cycles where annealing temperature was changed to $57^{\circ} \mathrm{C}$. Duplicate PCR reaction mixtures with all reagents except template DNA served as the negative control. Standards consisted of cloned DNA fragments (from sandy sediment samples from the Douro River estuary) that contain the target region of each primer set. The PCR product obtained was gel purified with the QIAquick gel extraction kit (Qiagen) and the amplicons cloned using the TOPO TA cloning kit (Invitrogen) according to the manufacturer's instructions, except for slight modifications (vector DNA and salt solution was decreased to $0.5 \mu \mathrm{l}$ and chemically competent cells decreased to $23 \mu \mathrm{l})$. Plasmids were isolated using the GeneElute plasmid miniprep kit (Sigma) and DNA concentrations of purified plasmids determined fluorometrically with PicoGreen ds DNA quantitation kit (Molecular Probes, Invitrogen). Standard curves were generated in duplicate for each primer set and amplification of standards was linear over 6 orders of magnitude, using different concentrations of plasmid DNA (from 0.2 to $0.2 \times 10^{-6}$ ng DNA); PCR reactions with standards and environmental samples were run together in the same PCR block. The $\mathrm{R}^{2}$ values between plasmid DNA copy numbers and the calculated threshold cycle value across the specified concentration ranged from 0.98 to 1.00 and amplification efficiency ranged between 95 and $101 \%$ for all standard curves generated. Target copy numbers for each reaction were calculated from the standard curves, assuming that the average molecular mass of a double-stranded DNA molecule is $618 \mathrm{~g}$ $\mathrm{mol}^{-1}$, and data are presented as number of gene copies $\mathrm{cm}^{-3}$ of sediment, based on the DNA extraction efficiency calculated above. Assuming that each Betaproteobacteria AOB carries 2 or 3 nearly identical copies of the amoA gene (Norton et al. 1996, 2002,
Bruns et al. 1998) and AOA carries 1 amoA gene copy cell $^{-1}$ (Hallam et al. 2006a, Agogué et al. 2008), Betaproteobacteria AOB amoA copy numbers were divided by 2.5 to convert values into numbers of cells. Melting curves and agarose gels of the qPCR products were run following each qPCR assay to confirm that the fluorescence signal originated from the specific PCR products (see an example in Fig. 1). Also, to confirm specificity of the qPCR assays, qPCR products from 2 environmental samples (July and October) generated by all primer sets were cloned as described above; 4 colonies were randomly selected from the library of each primer set, except for the AOA primer set, where a total of 50 colonies were randomly selected for the phylogenetic analysis of amo $A$ amplicons. Insert size was verified by digestion with EcoRI and 41 clones with the correct insert size were sequenced.

Phylogenetic analyses. All sequences were compared with reference sequences from GenBank using the basic local alignment search tool (BLAST; Altschul et al. 1990), and demonstrated specificity of the amplicons generated by qPCR with all primer sets. Phylogenetic analysis included the previously reported 745 sequences from soils (Francis et al. 2005, Leininger et al. 2006, He et al. 2007), marine water columns (Beman \& Francis 2006, Mincer et al. 2007), sediments (Francis et al. 2005), wastewater treatment plant bioreactors (Park et al. 2006), and amoA genes from Nitrosopumilus maritimus (Coolen et al. 2007) and Cenarchaeum symbiosum (Hallam et al. 2006b). In addition, a total of 168 sequences from unpublished studies that were available in the database were included in our analysis. Sequences were aligned with Clustal W (Thompson et al. 1994) as implemented in Bioedit version 7.0.5 (Hall 1999) and phylogenetic trees were inferred using the MEGA software package version 3.1 (Kumar et al. 2001), employing maximum parsimony and neighbour-joining methods for comparison. Bootstrap analysis was used to estimate the reliability of phylogenetic reconstructions (1000 replicates). Clone sequences from the present study were deposited in GenBank under accession numbers EU099927 to EU099966. 


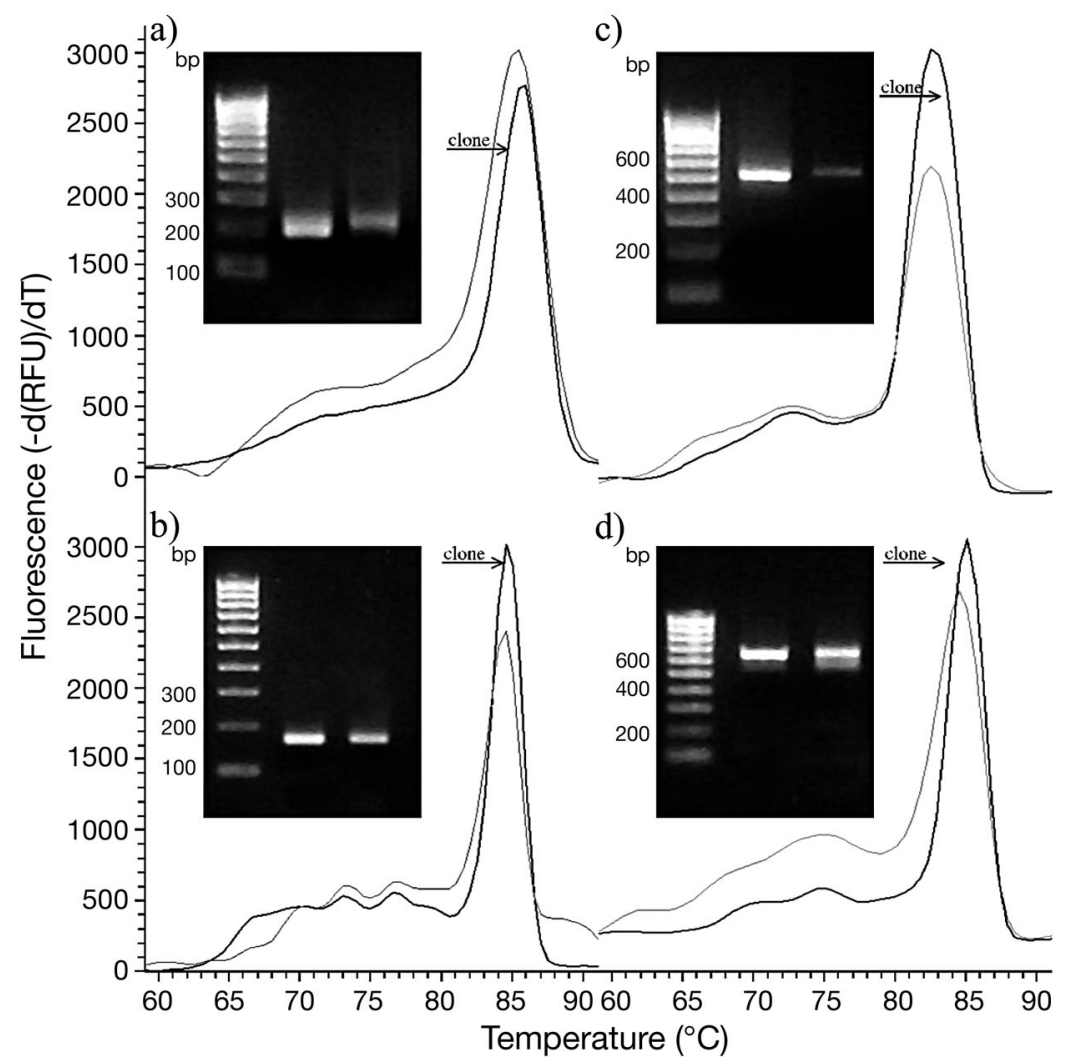

Fig. 1. Examples of clone (black lines) and respective environmental sample (grey lines; June) melting curve analysis of online PCR signals, and agarose gel $(2 \%)$ of amplification products for the 4 primer sets used to target the different groups of prokaryotes: (a) bacteria, (b) archaea, (c) ammonia-oxidizing bacteria (Betaproteobacteria AOB), and (d) ammonia-oxidizing archaea (AOA)

\section{RESULTS AND DISCUSSION}

\section{Microbial community structure}

In the sandy sediments of the Douro River estuary, bacteria greatly dominated over archaea, since archaeal 16S rRNA gene copy numbers represented just between 0.9 and $11.8 \%$ of the total bacterial $16 \mathrm{~S}$ rRNA gene copy numbers (Fig. 2). Bacterial plus archaeal 16S rRNA gene copy number quantification by real-time PCR based on 16S rRNA gene copy numbers agreed well with total counts of DAPI stained cells. A significant positive correlation was observed between bacterial plus archaeal 16S rRNA gene copy numbers and DAPI cell counts $(\mathrm{r}=0.63, \mathrm{p}=0.03, \mathrm{n}=$ $12)$, with the ratio between these variables being $1.5 \pm$ 1 (Fig. 3). Although archaea have been detected at up to $30 \%$ of total rRNA in marine picoplankton (DeLong et al. 1994), and represented (on average) $16 \%$ of the total DAPI stained cell counts in the water column of the Douro estuary (Abreu 2005), the domain Archaea represents a minor component (between 1 and $12 \%$ ) of the microbial community in many other habitats
(DeLong 1992, Massana et al. 1997, Sahm \& Berninger 1998, Sievert et al. 2000), with particularly low numbers obtained in sandy tidal flats $<1 \%$ of DAPI stained cell counts; Ishii et al. 2004). Total cell counts obtained in the present study are also in agreement with DAPI stained cell counts detected in sandy sediments elsewhere (LlobetBrossa et al. 1998, 2002). The lower abundance of bacteria in sandy sediments compared with fine sediments was already demonstrated in previous studies, and is attributed to the smaller specific surface area of these types of sediments (Llobet-Brossa et al. 1998, Rusch et al. 2003, Musat et al. 2006).

Betaproteobacteria AOB amoA copy numbers ranged from $0.8 \times 10^{6}$ to $7.5 \times$ $10^{6}$ gene copies $\mathrm{cm}^{-3}$ of sediment corresponding to 0.1 to $8.4 \%$ of the total bacterial 16S rRNA gene copies (Fig. 2). Archaeal amoA copy numbers varied between $0.9 \times 10^{5}$ to $8.6 \times 10^{5} \mathrm{~cm}^{-3}$ of sediment. Compared to total archaeal $16 \mathrm{~S}$ rRNA copy numbers, AOA amoA represented between 0.8 to $25.9 \%$ of the total archaeal community. Our results showed numerical dominance of bacterial over archaeal ammonia-oxidizers, with Betaproteobacteria $\mathrm{AOB} / \mathrm{AOA}$ ratios ranging from 1 to over 39 (Fig. 4). The ratio equaled 1 only in April when amoA gene copy numbers were similar in both populations (Figs. 2 \& 4). The percentages of Betaproteobacteria AOB to the total bacterial fraction are in agreement with the percentages previously reported in coastal marine sediments and wastewater treatment plants (0.01 to $5.7 \%$; Urakawa et al. 2006a, b). Moreover, Betaproteobacteria AOB amoA copy numbers of the Douro River intertidal sandy sediments fell within the range of Betaproteobacteria АОВ abundances reported in earlier studies performed in different sediment and soil ecosystems (Mendum et al. 1999, Hermansson \& Lindgren 2001, Leininger et al. 2006, Bernhard et al. 2007, He et al. 2007). AOA amoA copy numbers were found to be less abundant than in other soil systems, (Leininger et al. 2006), but are in the range of values reported for coastal permeable sediments (Santoro et al. 2008) and estuarine sediments (Mosier \& Francis 2008). Interestingly, these qPCR data disagree with recent reports for different ocean water masses (Hallam et al. 2006a, Wuchter et al. 2006, Mincer et al. 2007) or in distinct soil types (Leininger et al. 2006, Nicol et al. 2008), where Betaproteobacteria AOB amoA gene counts were found to be several orders of 

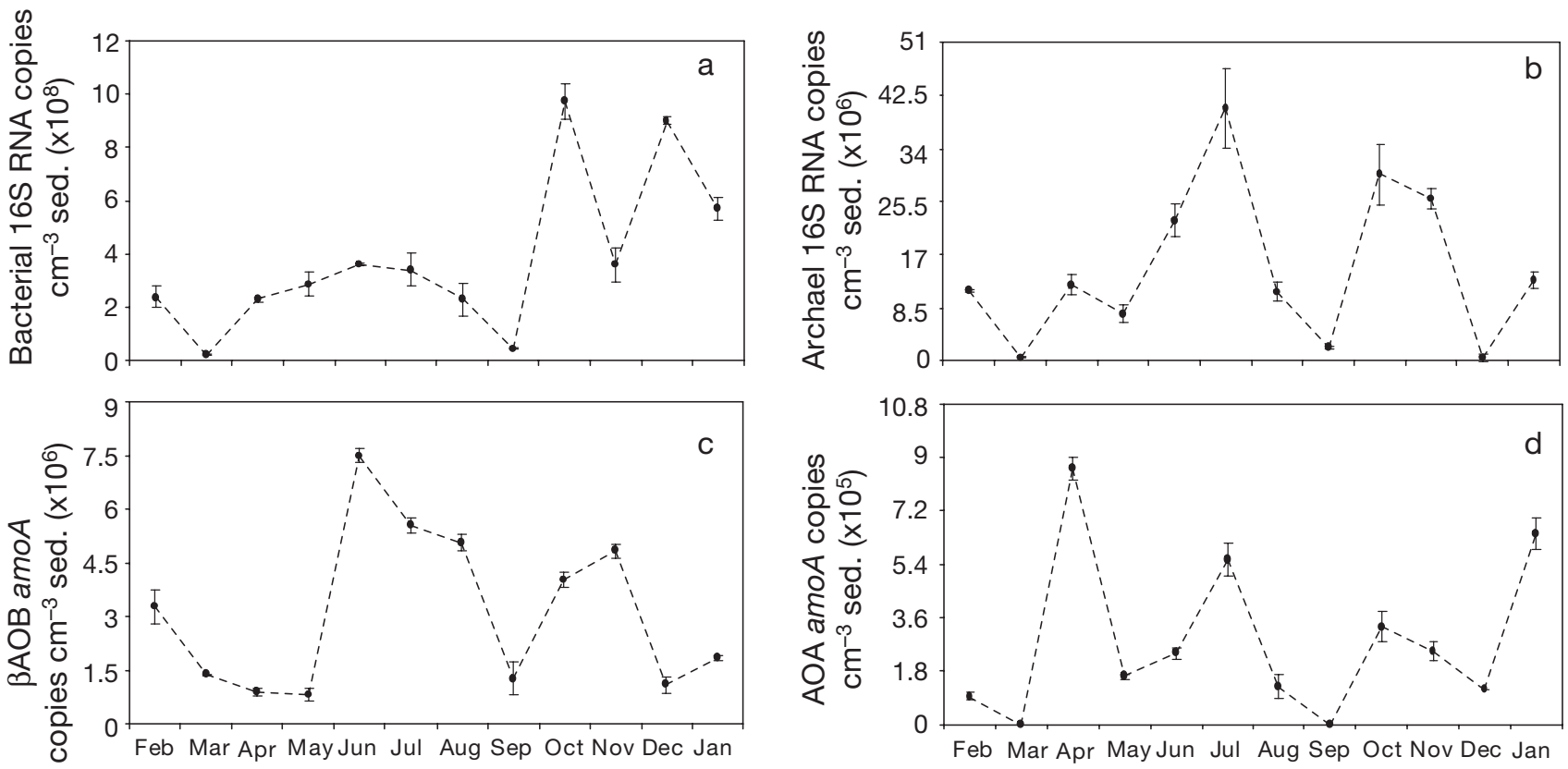

Fig. 2. 16S rRNA and $a m o A$ gene copy numbers (mean $\pm \mathrm{SD}, 2$ replicates) over 12 mo in intertidal sediments (sed.) of the Douro River estuary: (a) bacteria, (b) archaea, (c) ammonia-oxidizing bacteria (Betaproteobacteria AOB, $\beta A O B$ ), and (d) ammoniaoxidizing archaea (AOA)

magnitude lower than AOA amoA gene counts. However, in agreement with our results, a few recent studies have demonstrated that AOA are not always the most abundant ammonia-oxidizing microorganisms in the environment, by reporting that Betaproteobacteria AOB amoA may be several times more abundant than crenarchaeal amoA in different estuarine and coastal sediments examined (Caffrey et al. 2007, Mosier \& Francis 2008, Santoro et al. 2008).

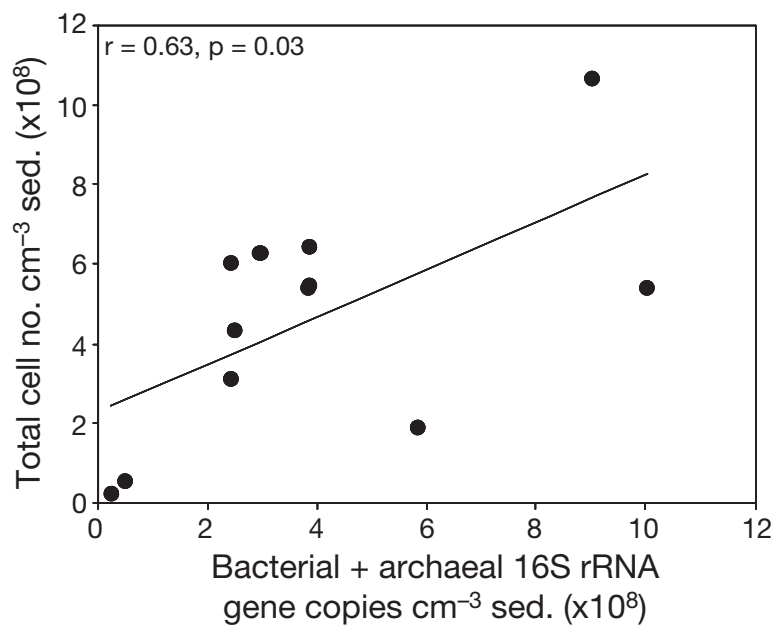

Fig. 3. Linear relationship between total cell counts determined by DAPI staining and bacterial + archaeal 16S rRNA gene copies determined by real-time PCR (qPCR) in intertidal sediments (sed.) of the Douro River estuary

\section{Temporal variability and environmental controls}

Different monthly patterns of variation were observed for total bacterial 16S rRNA and amoA copy numbers (Fig. 2). While bacterial 16S rRNA copy numbers reached maximum values in October and December, Betaproteobacteria AOB exhibited a peak in June. Results indicated that chl $a$ and total bacterial 16S rRNA copy numbers are significantly correlated $(\mathrm{r}=$ $0.81, \mathrm{p}=0.002, \mathrm{n}=12$ ). Covariance between algae and bacteria could reflect the reliance of bacteria on algae

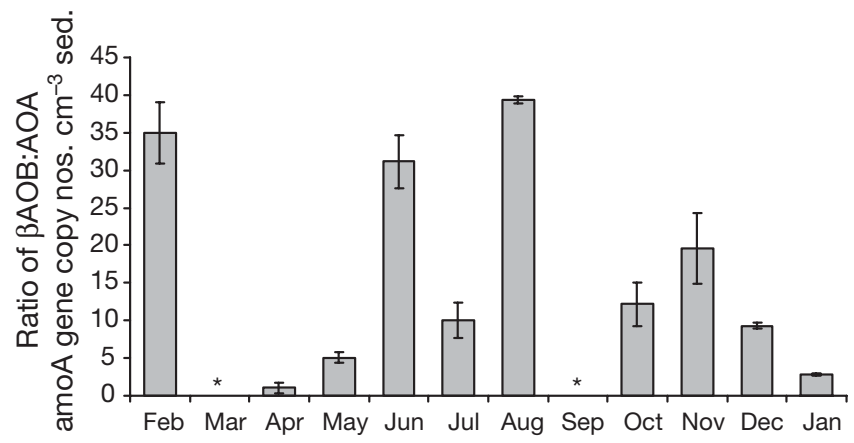

Fig. 4. Ratio of ammonia-oxidizing bacteria (Betaproteobacteria $\mathrm{AOB}, \beta \mathrm{AOB})$ to ammonia-oxidizing archaea (AOA) amoA gene copy nos. $\mathrm{cm}^{-3}$ sediment (sed.), over $12 \mathrm{mo}$ in intertidal sediments of the Douro River estuary. (*) No AOA detected, i.e. no specific products were formed upon $\mathrm{qPCR}$ 
for their organic carbon requirements (Gasol \& Duarte 2000), but also of algae on bacteria for nutrients (Zubkov \& Tarran 2008). Thus, these relationships suggest that bacterial production is being supported by algal-released DOC instead of allochthonous DOC. Archaeal 16S rRNA and amoA copy numbers exhibited similar seasonal patterns of variation, with minimum values observed in March and September and peaks of abundance observed in April, July, October and January, but with different relative amplitudes (Fig. 2b,d). Although Betaproteobacteria AOB:AOA ratios and archaeal 16S rRNA and amoA copy numbers were not related to any environmental variable evaluated in the present study, our results suggest that salinity may play a role in driving Betaproteobacteria AOB abundances. If data from May are considered to be an outlier, Betaproteobacteria AOB amoA gene copy numbers are positively and significantly related to salinity $(\mathrm{r}=0.60, \mathrm{p}=0.04, \mathrm{n}=11$; Fig. 5), with the highest $B e$ taproteobacteria AOB abundance being detected at higher salinities (Fig. 2, Table 2). Salinity was reported to be a key variable in selecting AOA and Betaproteobacteria AOB community shifts in coastal and estuarine sediments (Mosier \& Francis 2008, Santoro et al. 2008). Betaproteobacteria AOB were found to be $\sim 30 \times$ more abundant than AOA in saline stations of a sandy coastal sediment (Santoro et al. 2008), and AOA were found to be more abundant than Betaproteobacteria AOB only in the low salinity region of the San Francisco Bay estuary (Mosier \& Francis 2008). The fact that sandy sediments of the Douro River estuary are located in the lower stretch, characterized by almost permanently brackish water conditions (Table 2) (Vieira \& Bordalo 2000), could explain the dominance of Betaproteobacteria AOB over AOA during our 12 mo survey period (Fig. 2c,d). Shifts in the relative abundance

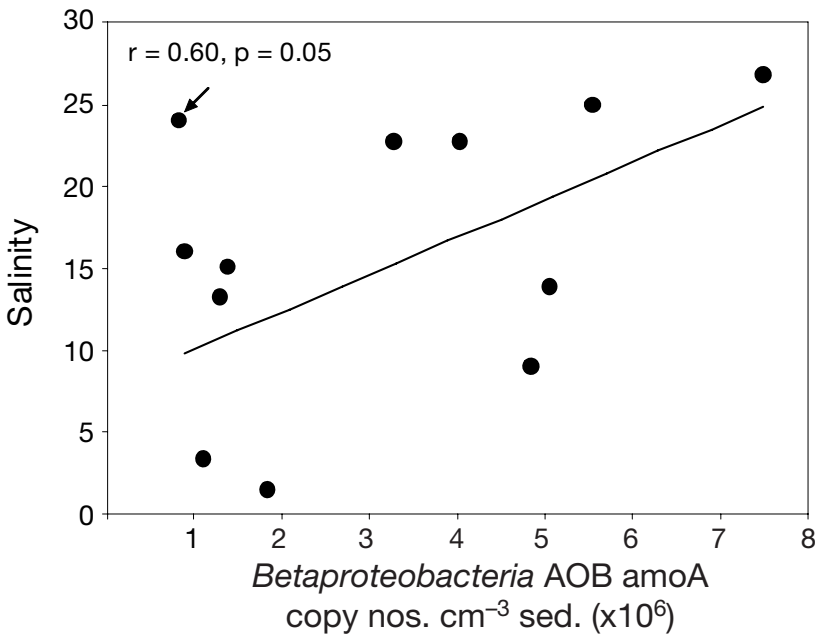

Fig. 5. Linear relationship between overlying water salinity and Betaproteobacteria AOB amoA gene copies determined by real-time PCR (qPCR) in intertidal sediments of the Douro River estuary. (Arrow) An outlier that was excluded in regression analysis

of ammonia-oxidizing bacteria and archaea have also been related to oxygen conditions in coastal sandy sediments (Santoro et al. 2008), in distinct soil types (Leininger et al. 2006) and in the Black Sea water column (Coolen et al. 2007, Lam et al. 2007). Results from these studies indicate higher relative AOA abundances in the suboxic and anoxic zones and higher levels of Betaproteobacteria AOB in higher-oxygen conditions, although maximum crenarchaeal amoA expression may not coincide with higher abundance of AOA amoA (Lam et al. 2007). The high permeability of the sandy sediments of the Douro River estuary that support aerobic metabolism in deeper layers (Huettel \& Gust 1992, Rusch et al. 2001), could also favour the dominance of Betaproteobacteria AOB over AOA.

Table 2. Potential nitrification rates, total cell counts (TCC), total organic matter (OM) and chl a concentrations in the sediment (sed.), and overlying water column inorganic nitrogen concentrations and salinity (mean $\pm \mathrm{SD}, 3$ replicates) during the monthly sampling survey. Columns 2 and 6-8 are data from Magalhães et al. (2005a)

\begin{tabular}{|c|c|c|c|c|c|c|c|}
\hline $2002-2003$ & $\begin{array}{l}\text { Nitrification } \\
\left(\mathrm{nmol} \mathrm{NH}_{4}^{+}\right. \\
\left.\mathrm{g}^{-1} \text { sed. } \mathrm{h}^{-1}\right)\end{array}$ & $\begin{array}{c}\mathrm{TCC} \\
\text { (cells } \mathrm{cm}^{-3} \text { sed.) }\end{array}$ & $\begin{array}{l}\mathrm{OM} \\
(\%)\end{array}$ & $\begin{array}{c}\text { Chl } a \\
\left(\mu \mathrm{g} \mathrm{g}^{-1} \text { sed.) }\right.\end{array}$ & $\begin{array}{l}\mathrm{NH}_{4}^{+} \\
(\mu \mathrm{M})\end{array}$ & $\begin{array}{c}\mathrm{NO}_{3}^{-}+\mathrm{NO}_{2}^{-} \\
(\mu \mathrm{M})\end{array}$ & Salinity \\
\hline Feb & $11.3 \pm 3.0$ & $4.3 \times 10^{8} \pm 0.4 \times 10^{7}$ & $0.7 \pm 0.6$ & $10.7 \pm 0.8$ & $21.1 \pm 1.7$ & $34.5 \pm 1.1$ & 22.7 \\
\hline Mar & $14.3 \pm 5.0$ & $0.2 \times 10^{8} \pm 8.0 \times 10^{7}$ & $0.1 \pm 0.2$ & $5.6 \pm 0.7$ & $21.9 \pm 0.9$ & $31.9 \pm 0.9$ & 15.1 \\
\hline Apr & $2.7 \pm 1.8$ & $3.1 \times 10^{8} \pm 3.7 \times 10^{7}$ & $0.7 \pm 0.3$ & $10.1 \pm 0.3$ & $38.6 \pm 3.3$ & $39.6 \pm 0.3$ & 16.0 \\
\hline May & $25.1 \pm 4.8$ & $6.3 \times 10^{8} \pm 4.1 \times 10^{7}$ & $0.4 \pm 0.3$ & $9.5 \pm 0.4$ & $36.9 \pm 1.4$ & $21.5 \pm 0.1$ & 24.0 \\
\hline Jun & $78.5 \pm 24.6$ & $6.4 \times 10^{8} \pm 8.7 \times 10^{7}$ & $0.3 \pm 0.4$ & $12.5 \pm 0.7$ & $100.0 \pm 6.4$ & $5.2 \pm 0.3$ & 26.8 \\
\hline July & $15.8 \pm 5.8$ & $5.4 \times 10^{8} \pm 1.6 \times 10^{7}$ & $1.3 \pm 0.8$ & $15.4 \pm 1.1$ & $22.0 \pm 3.3$ & $12.8 \pm 0.2$ & 25.0 \\
\hline Aug & $6.5 \pm 7.4$ & $6.1 \times 10^{8} \pm 5.4 \times 10^{7}$ & $0.9 \pm 0.8$ & $14.3 \pm 0.2$ & $40.8 \pm 2.4$ & $65.0 \pm 0.6$ & 13.9 \\
\hline Sep & $11.0 \pm 1.6$ & $0.6 \times 10^{8} \pm 1.1 \times 10^{7}$ & $0.3 \pm 0.4$ & $10.2 \pm 0.8$ & $168.7 \pm 2.2$ & $36.0 \pm 0.5$ & 13.2 \\
\hline Oct & $5.0 \pm 2.6$ & $5.4 \times 10^{8} \pm 9.5 \times 10^{7}$ & $0.3 \pm 0.4$ & $16.3 \pm 1.1$ & $49.9 \pm 3.3$ & $20.6 \pm 1.1$ & 22.7 \\
\hline Nov & $7.4 \pm 4.6$ & $5.5 \times 10^{8} \pm 1.1 \times 10^{7}$ & $0.2 \pm 0.1$ & $8.2 \pm 0.6$ & $121.7 \pm 1.7$ & $59.1 \pm 1.8$ & 9.0 \\
\hline Dec & $41.9 \pm 12.8$ & $10.7 \times 10^{8} \pm 5.7 \times 10^{7}$ & $0.2 \pm 0.2$ & $21.3 \pm 1.8$ & $46.7 \pm 2.7$ & $59.9 \pm 1.0$ & 3.4 \\
\hline Jan & $30.5 \pm 17.0$ & $1.9 \times 10^{8} \pm 1.1 \times 10^{7}$ & $0.4 \pm 0.3$ & $16.4 \pm 1.8$ & $65.4 \pm 2.6$ & $92.0 \pm 2.8$ & 1.5 \\
\hline
\end{tabular}




\section{Abundance and activities of betaproteobacterial AOB and AOA}

Previous results of $\mathrm{NH}_{4}{ }^{+}$enrichment experiments conducted in the same sediment site of the Douro River estuary (Magalhães et al. 2005a) showed that nitrification rates were stimulated by $\mathrm{NH}_{4}{ }^{+}$availability up to $\sim 100 \mu \mathrm{M}$, but that nitrification rates were inhibited at higher $\mathrm{NH}_{4}{ }^{+}$concentrations. These findings corroborate betaproteobacterial AOB abundance values presented here, since the highest Betaproteobacteria AOB amoA copy number was observed in June $\left(7.5 \times 10^{6}\right.$ copies $\mathrm{cm}^{-3}$ sed.) when $\mathrm{NH}_{4}{ }^{+}$concentration was close to $100 \mu \mathrm{M}$, and lower amoA copy numbers were observed in September and November (Fig. 2) when $\mathrm{NH}_{4}{ }^{+}$concentrations were $>100 \mu \mathrm{M}$ of $\mathrm{NH}_{4}{ }^{+}$(Table 2). This variability in Betaproteobacteria AOB abundance values is also in agreement with monthly data for nitrification rates that showed a peak in June and lower values at higher $\mathrm{NH}_{4}{ }^{+}$concentrations (Table 2, Fig. 2). In contrast, AOA amoA gene copy numbers were not related to $\mathrm{NH}_{4}{ }^{+}$availability or to nitrification rates.

Published cell-specific ammonia-oxidation in pure cultures revealed that rates could range between 0.3 to $53 \mathrm{fmol}$ of $\mathrm{N}$ cell ${ }^{-1} \mathrm{~h}^{-1}$ (Skinner \& Walker 1961, Ward 1987, Ward et al. 1989, Laanbroek \& Gerards 1993). In addition, in situ cellular rates of ammoniaoxidation were found to be equally variable (between 0.03 and 43 fmol of $\mathrm{N}$ cell $^{-1} \mathrm{~h}^{-1}$; c.f. Coskuner et al. 2005). If the amoA copy numbers are divided by 2.5 , the abundance of Betaproteobacteria AOB present in the sandy flat of Douro estuary might support the nitrification rates measured in the same samples (5.0 \pm 2.6 to $78.5 \pm 24.6 \mathrm{nmol} \mathrm{NH}_{4}^{+} \mathrm{g}$ sed. ${ }^{-1} \mathrm{~h}^{-1}$; Table 2). Nitrification rates would range between 6.6 to $60.0 \mathrm{nmol} \mathrm{NH}_{4}^{+} \mathrm{g} \mathrm{sed.} .^{-1} \mathrm{~h}^{-1}$ if cell-specific ammoniaoxidation were $20 \mathrm{fmol}$ of $\mathrm{N}$ cell $^{-1} \mathrm{~h}^{-1}$. AOA amoA gene copy numbers obtained (Fig. 2) accounted (on average) for 1.9 to $17.3 \mathrm{nmol} \mathrm{NH}_{4}{ }^{+} \mathrm{g} \mathrm{sed} .^{-1} \mathrm{~h}^{-1}$, assuming the same cell-specific ammonia-oxidation rate and that AOA have 1 copy of $a m o A$ cell $^{-1}$; this is not sufficient to explain the higher nitrification rates measured (Table 2). Thus, the numerical abundance of Betaproteobacteria AOB amoA genes compared with those of AOA, and the fact that AOA amoA gene copy numbers were not related to $\mathrm{NH}_{4}{ }^{+}$availability or to nitrification rates, suggest that Betaproteobacteria AOB (mainly composed of Nitrosospira-like species (Magalhães et al. 2007) are more active contributors to nitrification processes in the sandy flat of the Douro River estuary. However, although most of the environmental studies, including the present one, have focused on the Betaproteobacteria AOB, ammonia oxidizers that belong to Gammaproteobacteria might also contribute to the rates of nitrification measured (Lam et al. 2007).

\section{AOA diversity}

To assess AOA diversity, archaeal amoA gene libraries were generated. From a total of 41 sequenced clones, 23 operational taxonomic units (OTUs, based on a $2 \%$ cutoff) were recovered. AmoA sequences were compared with the nearest environmental sequences in the databases to explore the distribution and coverage of the AOA community that inhabit sandy sediments of the Douro River estuary. Phylogenetic analysis (Fig. 6) revealed that all archaeal amoA sequences retrieved from Douro River estuarine sediments were closely related to sequences previously classified as sequences from the 'water column', 'sediments', and 'soil/sediments' (Francis et al. 2005, Park et al. 2006). The recovered $a m o A$ sequences had 70 to $100 \%$ identities between each other and fell into 7 distinct phylogenetic clusters throughout the phylogenetic tree (Fig. 6). Most of the recovered sequences $(71 \%)$ fell into the 'sediments' and 'sediment/soil' clusters previously described by Francis et al. (2005). Sequences that fell into the 'sediments' cluster shared 80 to $90 \%$ nucleotide sequence identity with Nitrosopumilus maritimus (Könneke et al. 2005), and were most closely related (with 81 to $99 \%$ similarities) to sequences from different estuarine sediments. The $34 \%$ of sequences that fell into the sediment/soil cluster included sequences from distinct soil types (Leininger et al. 2006, He et al. 2007, S. Avrahami et al. unpubl., S. A. Wakelin \& J. R. Stephen unpubl.), from estuarine sediments (Francis et al. 2005, Beman \& Francis 2006), from San Francisco Bay sediments (Park et al. 2006), and from wastewater treatment plant bioreactors (Park et al. 2006). Two of the recovered sequences (Clones A13 and A16) clustered together with the amoA gene from soil fosmid; these sequences had nucleotide identities of $98 \%$ (Fig. 6). Interestingly, 10 of the recovered sequences fell into previously described water column Cluster A (Francis et al. 2005), and showed between 81 to $86 \%$ nucleotide identity with sequences from Monterey Bay, the Black Sea, eastern tropical North Pacific water columns (Francis et al. 2005) and from Oahu seawater in Hawaii (Mincer et al. 2007). Douro River estuarine sediment clones included in this cluster had between 74 and $80 \%$ similarities with sequences that fell into the well supported clade (bootstrap value, 100\%) previously described as water column Cluster B (Francis et al. 2005), that comprises water column sequences from different geographical locations (Fig. 6). Based on phylogenetic analyses, crenarchaeal amoA sequences recovered in the present study showed a fair diversity, with representatives in a number of previously defined clusters. In addition, 2 sequences (Clones A37 and O5) seemed to form a novel cluster together with one other 


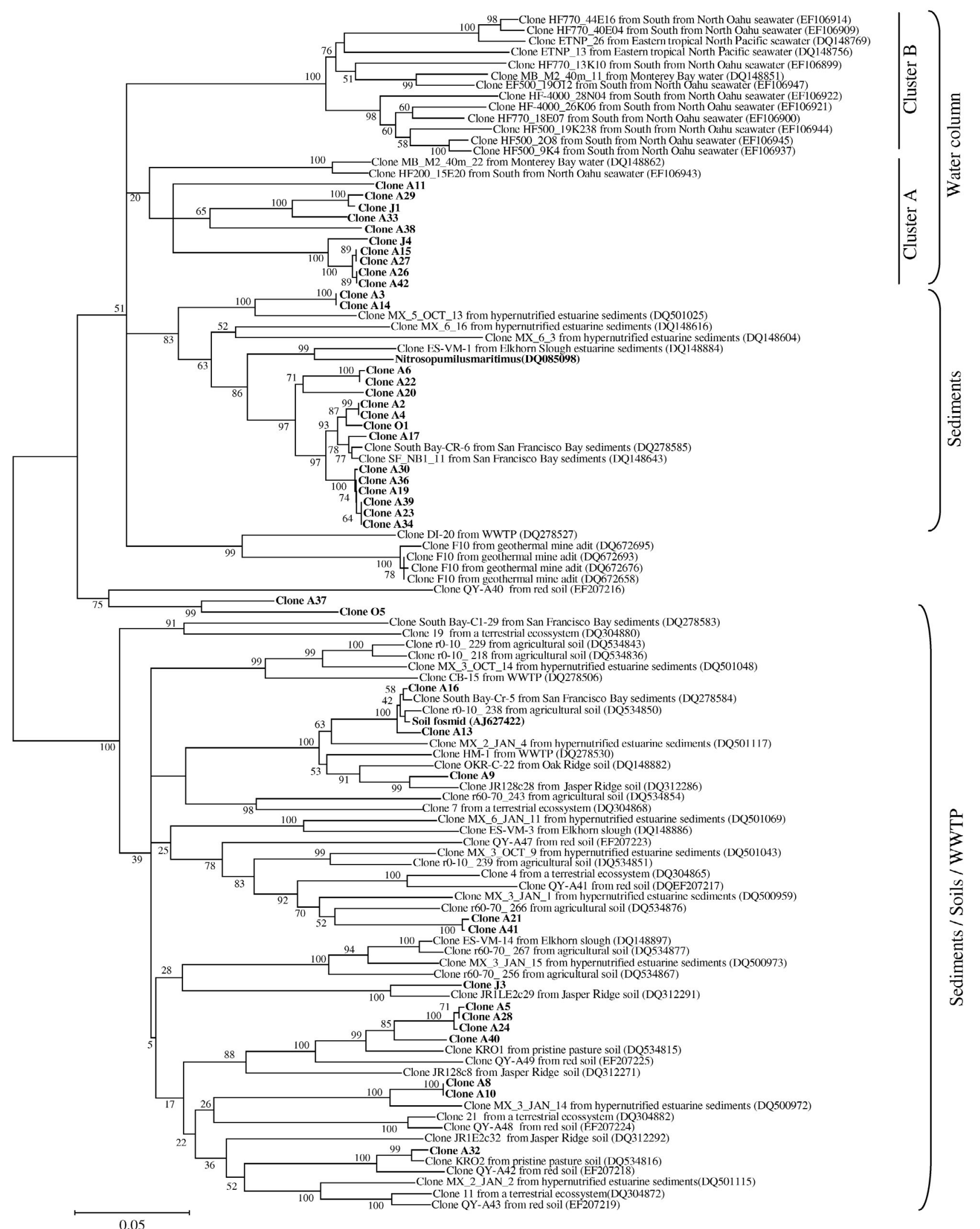

Fig. 6. Phylogenetic relationship among archaeal amoA sequences retrieved from intertidal flats of the Douro estuary and other different geographic locations. The unrooted neighbor-joining tree was based on 591 nucleotide sequences and was constructed based on Kimura distances and the neighbor-joining method. Distance bootstrap values $>50 \%$ are indicated at branch points (1000 iterations). The major clusters indicated were also supported using maximum parsimony analysis. Clones obtained from this study are shown in bold. Scale bar indicates Kimura distance 
sequence in the data base obtained from red soils (He et al. 2007). Overall, our findings suggest that both benthic and planktonic AOA populations were associated with the sandy flat of the Douro River estuary. This may be related to the fact that the system is subjected to semidiurnal tides (Vieira \& Bordalo 2000), resulting in immersion and emersion every $6 \mathrm{~h}$ that may select for both planktonic and benthic communities adapted to 2 different habitats (pelagic and benthic).

\section{CONCLUSIONS}

While there are still few available environmental studies on the relative abundance of Betaproteobacteria $\mathrm{AOB}$ vs. AOA, these studies show the occurrence of higher archaea-like than bacteria-like amoA gene numbers in soils, estuarine sediments and ocean waters (e.g. Hallam et al. 2006a, Leininger et al. 2006, Wuchter et al. 2006, Mincer et al. 2007, Nicol et al. 2008), with the exception of a few studies (Caffrey et al. 2007, Mosier \& Francis 2008, Santoro et al. 2008). Here, we confirm that at least in our estuarine environment, Betaproteobacteria AOB amoA copy numbers clearly dominate over those of AOA amoA almost year round. In concordance, relationships established with nitrification rates and nitrification rate estimations based on cell-specific ammonia-oxidation suggest that Betaproteobacteria AOB may play a greater role than AOA in nitrification processes in these aerobic sandy sediments. While more detailed studies are needed to fully understand the environmental variables that control the relative abundance of ammonia-oxidizing bacteria and archaea in natural environments, our results indicate that salinity may play a decisive role in controlling shifts in the dominance of these communities. Phylogenetic analysis revealed that the archaeal ammonia-oxidizing community in the sandy intertidal flat of the Douro River estuary is composed of a combination of planktonic and benthic assemblages that are well adapted to the semidiurnal tidal regime in this temperate estuary. Finally, the observations reported in the present study contribute to the improvement of our knowledge on the relative contributions of Betaproteobacteria $\mathrm{AOB}$ and $\mathrm{AOA}$ to nitrification processes, and on the global diversity and distribution of AOA amoA-like genes.

Acknowledgements. We thank M. J. Magalhães, I. Azevedo, S. Ramos and R. Moreira, for assistance in fieldwork and during the incubations; and L. Torgo for support in data analysis. We also thank W. J. Wiebe and 3 anonymous reviewers for their extremely helpful comments on the manuscript; K. M. Kalanetra and N. Bano for reviewing real-time PCR calculations; Bio-Rad Portugal for the loan of the real-time PCR sys- tem (MiniOpticon CFB-3120); and E. Lopes for valuable assistance and advice. This study was funded by the Portuguese Science and Technology Foundation (FCT) through a Postdoctoral fellowship to C.M.M. (SFRH/BPD/14929/2004).

\section{LITERATURE CITED}

Abreu C (2005) Application of molecular techniques to the study of bacteria and archaea populations in the River Douro estuary. PhD dissertation, University of Porto, Portugal

> Agogué H, Brink M, Dinasquet J, Herndl GJ (2008) Major gradients in putatively nitrifying and non-nitrifying Archaea in the deep North Atlantic. Nature 456:788-791

> Altschul SF, Gish W, Miller W, Myers EW, Lipman DJ (1990) Basic local alignment search tool. J Mol Biol 215:403-410

> Beman JM, Francis CA (2006) Diversity of ammonia-oxidizing archaea and bacteria in the sediments of a hypernutrified subtropical estuary: Bahía del Tóbari, Mexico. Appl Environ Microbiol 72:7767-7777

Bernhard AE, Tucker J, Giblin AE, Stahl DA (2007) Functionally distinct communities of ammonia-oxidizing bacteria along an estuarine salinity gradient. Environ Microbiol 9: 1439-1447

Bruns MA, Fries MR, Tiedje JM, Paul EA (1998) Functional gene hybridization patterns of terrestrial ammonia-oxidizing bacteria. Microb Ecol 36:293-302

Caffrey JM, Bano N, Kalanetra K, Hollibaugh JT (2007) ammonia-oxidation and ammonia-oxidizing bacteria and archaea from estuaries with differing histories of hypoxia. ISME J 1:660-662

Coolen MJL, Abbas B, van Bleijswijk J, Hopmans EC, Kuypers MMM, Wakeham SG, Damsté JSS (2007) Putative ammonia-oxidizing Crenarchaeota in suboxic waters of the Black Sea: a basin-wide ecological study using 16S ribosomal and functional genes and membrane lipids. Environ Microbiol 9:1001-1016

> Coskuner G, Ballinger SJ, Davenport RJ, Pickering RL, Solera R, Head IM, Curtis TP (2005) Agreement between theory and measurement in quantification of ammonia-oxidizing bacteria. Appl Environ Microbiol 71:6325-6334

> Dang H, Zhang X, Sun J, Li T, Zhang Z, Yang G (2008) Diversity and spatial distribution of sediment ammonia-oxidizing crenarchaeota in response to estuarine and environmental gradients in the Changjiang Estuary and East China Sea. Microbiology 154:2084-2095

> DeLong EF (1992) Archaea in coastal marine environments. Proc Natl Acad Sci USA 89:5685-5689

> DeLong EF, Ying Wu K, Prezelin BB, Jovine RVM (1994) High abundance of Archaea in Antarctic marine picoplankton. Nature 371:695-697

Francis CA, Roberts KJ, Beman JM, Santoro AE, Oakley BB (2005) Ubiquity and diversity of ammonia-oxidizing archaea in water columns and sediments of the ocean. Proc Natl Acad Sci USA 102:14683-14688

> Gasol JM, Duarte CM (2000) Comparative analyses in aquatic microbial ecology: How far do they go? FEMS Microbiol Ecol 31:99-106

Hall TA (1999) BioEdit: a user-friendly biological sequence alignment editor and analysis program for Windows 95/98/NT. Nucleic Acids Symp Ser 41:95-98

- Hallam SJ, Konstantinidis KT, Putnam N, Schleper C and others (2006a) Genomic analysis of the uncultivated marine crenarchaeote Cenarchaeum symbiosum. Proc Natl Acad Sci USA 103:18296-18301

Hallam SJ, Mincer TJ, Schleper C, Preston CM, Roberts K, 
Richardson PM, DeLong EF (2006b) Pathways of carbon assimilation and ammonia-oxidation suggested by environmental genomic analyses of marine Crenarchaeota. PLoS Biol 4:e95

He J-Z, Shen J-P, Zhang L-M, Zhu Y-G, Zheng Y-M, Xu M-G, Di M. (2007) Quantitative analyses of the abundance and composition of ammonia-oxidizing bacteria and ammoniaoxidizing archaea of a Chinese upland red soil under longterm fertilization practices. Environ Microbiol 9: $2364-2374$

> Hermansson A, Lindgren PE (2001) Quantification of ammonia-oxidizing bacteria in arable soil by real-time PCR. Appl Environ Microbiol 67:972-976

> Huettel M, Gust G (1992) Impact of bioroughness on interfacial solute exchange in permeable sediments. Mar Ecol Prog Ser 89:253-267

Ishii K, Mussmann M, MacGregor BJ, Amann R (2004) An improved fluorescence in situ hybridization protocol for the identification of bacteria and archaea in marine sediments. FEMS Microbiol Ecol 50:203-213

> Könneke M, Bernhard AE, de la Torre JR, Walker CB, Waterbury JB, Stahl DA (2005) Isolation of an autotrophic ammonia-oxidizing marine archaeon. Nature 437:543-546

Kumar S, Tamura K, Jakobsen IB, Nei M (2001) Mega 2: molecular evolutionary genetics analysis software. Bioinformatics Appl Notes 17:1244-1245

> Laanbroek HJ, Gerards S (1993) Competition for limiting amounts of oxygen between Nitrosomonas europaea and Nitrobacter winogradskyi grown in mixed continuous culture. Arch Microbiol 159:453-459

Lam P, Jensen MM, Lavik G, McGinnis DF and others (2007) Linking crenarchaeal and bacterial nitrification to anammox in the Black Sea. Proc Natl Acad Sci USA 104: 7104-7109

Leininger S, Urich T, Schloter M, Schwark L and others (2006) Archaea predominance among ammonia-oxidizing prokaryotes. Nature 442:806-809

Llobet-Brossa E, Rosselló-Mora R, Amann R (1998) Microbial community composition of Wadden Sea sediments as revealed by fluorescence in situ hybridization. Appl Environ Microbiol 64:2691-2696

Llobet-Brossa E, Rabus R, Böttcher ME, Könneke M and others (2002) Community structure and activity of sulfate reducing bacteria in an intertidal surface sediment: a multi-method approach. Aquat Microb Ecol 29:211-226

> Magalhães CM, Joye SB, Moreira RM, Wiebe WJ, Bordalo AA (2005a) Effect of salinity and inorganic nitrogen concentrations on nitrification and denitrification rates in intertidal sediments and rocky biofilms of the Douro River estuary, Portugal. Water Res 39:1783-1794

Magalhães CM, Wiebe WJ, Joye SB, Bordalo AA (2005b) Inorganic nitrogen dynamics in intertidal rocky biofilms and sediments of the Douro River estuary (Portugal). Estuaries 28:592-606

- Magalhães CM, Bano N, Wiebe WJ, Hollibaugh JT, Bordalo AA (2007) Composition and activity of beta-proteobacteria ammonia-oxidizing communities associated with intertidal rocky biofilms and sediments of the Douro River estuary, Portugal. J Appl Microbiol 103:1239-1250

- Massana R, Murray AE, Preston CM, DeLong EF (1997) Vertical distribution and phylogenetic characterization of marine planktonic Archaea in the Santa Barbara channel. Appl Environ Microbiol 63:50-56

> Mendum TA, Sockett RE, Hirsch PR (1999) Use of molecular and isotopic techniques to monitor the response of autotrophic ammonia-oxidizing populations of the, subdivision of the class Proteobacteria in arable soils to nitrogen fertilizer. Appl Environ Microbiol 65:4155-4162

Miller LG, Sasson C, Oreland RS (1998) Difluoromethane, a new and improved inhibitor of methanotrophy. Appl Environ Microbiol 64:4357-4362

Mincer TJ, Church MJ, Taylor LT, Preston C, Karl DM, Delong EF (2007) Quantitative distribution of presumptive archaeal and bacterial nitrifiers in Monterey Bay and the North Pacific subtropical gyre. Environ Microbiol 9: $1162-1175$

Moran MA, Buchan A, Gonzalez JM, Heidelberg JF and others (2004) Genome sequence of Silibacter pomeroyi reveals adaptations to the marine environment. Nature 432:910-913

> Mosier AC, Francis CA (2008) Relative abundance and diversity of ammonia-oxidizing archaea and bacteria in the San Francisco Bay estuary. Environ Microbiol 10:3002-3016

Mucha APM, Vasconcelos TSD, Bordalo AA (2003) Macrobenthic community in the Douro estuary: relations with trace metals and natural sediment characteristics. Environ Pollut 121:169-180

> Mumy KL, Findlay RH (2004) Convenient determination of DNA extraction efficiency using an external DNA recovery standard and quantitative-competitive PCR. J Microbiol Methods 57:259-268

> Musat N, Werner U, Knittel K, Kolb S and others (2006). Microbial community structure of sandy intertidal sediments in the North Sea, Sylt-Rømø Basin, Wadden Sea. Syst Appl Microbiol 29:333-348

> Muyzer G, de Waal EC, Uitterlinder AG (1993) Profiling of complex microbial populations by denaturing gradient gel electrophoresis analysis of polymerase chain reactionamplified genes coding for 16S rRNA. Appl Environ Microbiol 59:695-700

> Nicol GW, Leininger S, Schleper C, Prosser JI (2008) The influence of soil $\mathrm{pH}$ on the diversity, abundance and transcriptional activity of ammonia oxidizing archaea and bacteria. Environ Microbiol 10:2966-2978

> Norton JM, Low JM, Klotz MG (1996) The gene encoding ammonia monooxygenase subunit A exists in nearly three identical copies in Nitrosospira sp. NpAV. FEMS Microbiol Lett 139:181-188

Norton JM, Alzerreca JJ, Suwa Y, Klotz MG (2002) Diversity of ammonia monooxygenase operon in autotrophic ammonia-oxidizing bacteria. Arch Microbiol 177:139-149

> Okano Y, Hristova KR, Leutenegger CM, Jackson LE and others (2004) Application of real-time PCR to study effects of ammonium on population size of ammonia-oxidizing bacteria in soil. Appl Environ Microbiol 70:1008-1016

Park HD, Wells GF, Bae H, Criddle CS, Francis CA (2006) Occurrence of ammonia-oxidizing archaea in wastewater treatment plant bioreactors. Appl Environ Microbiol 72:5643-5647

Porter KG, Feig YS (1980) The use of DAPI for identifying and counting aquatic microflora. Limnol Oceanogr 25:943-948

Rotthauwe JH, Witzel KP, Liesack W (1997) The ammonia monooxygenase structural gene $a m o A$ as a functional marker: molecular fine-scale analysis of natural ammoniaoxidizing populations. Appl Environ Microbiol 63: $4704-4712$

Rusch A, Huettel M, Reimers CE, Taghon GL, Fuller CM (2001) Bacteria, diatoms and detritus in an intertidal sandflat subjected to advective transport across the watersediment interface. Biogeochemistry 55:1-27

> Rusch A, Huettel M, Reimers CE, Taghon GL, Fuller CM (2003) Activity and distribution of bacterial populations in Middle Atlantic Bight shelf sands. FEMS Microbiol Ecol 44:89-100 
Sahm K, Berninger UG (1998) Abundance, vertical distribution, and community structure of benthic prokaryotes from permanently cold marine sediments (Svalbard, Arctic Ocean). Mar Ecol Prog Ser 165:71-80

Santoro AE, Francis CA, de Sieyes NR, Boehm BB (2008) Shifts in the relative abundance of ammonia-oxidizing bacteria and archaea across physicochemical gradients in a subterranean estuary. Environ Microbiol 10: 1068-1079

Sievert SM, Ziebis W, Kuever J, Sahm K (2000) Relative abundance of Archaea and Bacteria along a thermal gradient of a shallow-water hydrothermal vent quantified by rRNA slot-blot hybridization. Microbiol 146:1287-1293

Skinner FA, Walker N (1961) Growth of Nitrosomonas europaea in batch continuous culture. Arch Microbiol 38:339-349

Suzuki MT, Taylor LT, DeLong EF (2000) Quantitative analysis of small-subunit rRNA genes in mixed microbial populations via 5'-nuclease assays. Appl Environ Microbiol 66:4605-4614

Thompson JD, Higgins DG, Gibson TJ (1994) Clustal W: improving the sensitivity of progressive multiple sequence alignment through sequence weighting, position-specific gap penalties and weight matrix choice. Nucleic Acids Res

Editorial responsibility: Antje Boetius,

Bremen, Germany
22:4673-4680

Urakawa H, Kurata S, Fujiwara T, Kuroiwa D and others (2006a) Characterization and quantification of ammoniaoxidizing bacteria in eutrophic coastal marine sediments using polyphasic molecular approaches and immunofluorescence staining. Environ Microbiol 8:787-803

- Urakawa H, Maki H, Kawabata S, Fujiwara T and others (2006b) Abundance and population structure of ammoniaoxidizing bacteria that inhabit canal sediments receiving effluents from municipal wastewater treatment plants. Appl Environ Microbiol 72:6845-6850

Vieira MEC, Bordalo AA (2000) The Douro estuary (Portugal): a mesotidal salt wedge. Oceanol Acta 23:585-594

Ward BB (1987) Nitrogen transformations in the Southern California Bight. Deep-Sea Res 34:785-805

> Ward BB, Glover HE, Lipschultz F (1989) Chemoautotrophic activity and nitrification in the oxygen minimum zone off Peru. Deep-Sea Res 36:1031-1051

Wuchter C, Abbas B, Coolen MJL, Herfort L and others (2006) Archaeal nitrification in the ocean. Proc Natl Acad Sci USA 103:12317-12322

Zubkov MV, Tarran GA (2008) High bacterivory by the smallest phytoplankton in the North Atlantic Ocean. Nature 455:224-226

Submitted: April 16, 2008; Accepted: April 14, 2008

Proofs received from author(s): June 30, 2009 